\title{
Praktikalitas Perancangan Media e-Learning Berbasis Video
}

\author{
Studi Perancangan e-Learning dengan Open Source \\ Moodle di SMA Sungai Penuh, Jambi
}

\author{
${ }^{1)}$ Eril Syahmaidi, ${ }^{2)}$ Hendra Hidayat \\ ${ }^{1)}$ Program Studi Pendidikan Teknik Informatika dan Komputer \\ ${ }^{2)}$ Pendidikan Guru Sekolah Dasar \\ Fakultas Keguruan dan Ilmu Pendidikan \\ Universitas Bung Hatta, Jln, Aie Pacah \\ Padang, Indonesia \\ erilsyahmaidimpd@gmail.com
}

\begin{abstract}
Abstrak
Penelitian ini bertujuan untuk menghasilkan rancangan media pembelajaran berupa media $e$-learning berbasis video yang praktis untuk pelajaran Teknologi Informasi dan Komunikasi. Jenis penelitian ini adalah penelitian pengembangan dengan menggunakan model IDI (Instructional Development Institute). Penelitian ini melihat apakah media $e$ learning berbasis video yang dirancang ini praktis, kemudian dilakukan uji coba kepada pengguna, yaitu guru dan siswa. Aspek yang diuji cobakan kepada guru untuk melihat aspek akses $e$-learning, aspek materi, aspek penyajian, aspek media $e$-learning berbasis video. Hasil penelitian menunjukkan bahwa media e-learning berbasis video oleh guru sudah praktis, sedangkan kepada siswa untuk melihat minat siswa, proses penggunaannya, peningkatan keaktifan siswa dan waktu siswa dalam mempelajari Mata Pelajaran Teknologi Informasi dan Komunikasi di SMA dengan menggunakan media E-Learning Berbasis Video. Hasil praktikalitas oleh siswa sudah praktis. Berdasarkan data di atas dapat disimpulkan bahwa media e-learning berbasis video telah praktis dan dapat digunakan dalam pembelajaran di SMA dan dapat dikembangkan serta digunakan pada mata pelajaran yang berbeda.

Kata Kunci: Media, E-learning, Video, Praktis.
\end{abstract}

\section{Pendahuluan}

Teknologi informasi beberapa tahun belakangan ini berkembang dengan begitu cepat disebabkan perkembangan teknologi saat ini begitu mengubah pola fikir manusia menjadi lebih maju dalam kemajuan teknologi diharapkan manusia lebih berkembang dalam hal pengetahuan terhadap perkembangan zaman.

E-learning merupakan salah satu bentuk dari media komunikasi. "Media komunikasi bukan saja dapat mempermudah dan mengefektifkan proses pembelajaran, tetapi 
juga bisa membuat proses pembelajaran menjadi menarik" [1]. E-learning sebagai bagian dari media komunikasi memiliki banyak kelebihan misalnya siswa cukup mendownload materi untuk belajar, ujian online tetapi belum dilengkapi dengan video tutorial. E-learning merupakan media alat bantu di dalam pembelajaran khususnya sebagai media pembelajaran siswa di luar sekolah.

Banyak altenatif cara pembelajaran dari berkembangnya teknologi seperti perpustakaan online, e-learning, pembuatan $\mathrm{CD}$ interaktif, virtual university dan lain sebagainya. Sistem ini memanfaatkan media komputer dan jaringan sebagai sistem pembelajarannya. Di mana proses pembelajaran yang sebelumnya menggunakan tatap muka di dalam kelas diperluas jangkauannya dengan menggunakan sistem e-learning atau seiring dengan perkembangan teknologi dikenalah istilah pendidikan jarak jauh. Menurut [2] ciri-ciri pembelajaran jarak jauh adalah adanya organisasi yang mengatur cara belajar mandiri, materi pembelajaran disampaikan melalui media, dan tidak ada kontak langsung antar siswa dan pengajar.

Menurut Undang-Undang 20 Tahun 2003 tentang Sistim Pendidikan Nasional (SISDIKNAS), yang dimaksud dengan pendidikan jarak jauh adalah "pendidikan yang pesertanya didiknya terpisah dari pendidik dan pembelajarannya menggunakan berbagai sumber belajar melalui teknologi komunikasi, informasi dan media lainnya".

Saat ini pendidikan berbasis e-learning telah menjadi trend dan bahkan telah menjadi tuntutan tersendiri bagi institusiinstitusi penyelenggara pendidikan terutama pendidikan jarak jauh. Beberapa alasan utama, untuk menggunakan media $e$ learning, menurut [3] antara lain: (1) meningkatkan akses dan fleksibelitas (Improved access dan flexibility); (2) cepat dalam penyebaran dan hemat (Faster delivery and cost savings); (3) peningkatan dan pengawasan Standarisasi (Improved control and standardization); dan (4) Memperbaiki Komunikasi dan Kerjasama (Enhanced communication and Collaboration). Disamping itu, menurut banyak penelitian sebelumnya, lingkungan $e$ learning menggunakan gaya belajar yang spesifik sehingga lebih efisien untuk proses pembelajaran dan mengurangi periode waktu untuk belajar [4], [5], [6], [7], [8], [9], [10], [11], [12].

Implementasi metode pembelajaran berbasis e-learning saat ini masih banyak berperan sebagai pelengkap pembelajaran yang dilaksanakan secara tatap muka, baik terhadap proses belajar mengajar pada jenis pendidikan akademik maupun profesi. Salah satu penyebab utamanya adalah masalah infrastruktur, terutama ketersediaan jaringan internet serta rendahnya bandwith yang ada dan harganya yang masih tergolong mahal. Di samping itu, lemahnya kualitas dan kontrol dalam metode pendidikan e-learning ini menjadi permasalahan tersendiri bagi penyelenggara pendidikan serta kemajuan teknologi memungkinkan peserta didik untuk berperan aktif didalam melakukan pembelajaran. Sudah ada bukti empiris tentang pengaruh positif pada kinerja siswa dari penerapan inovasi dalam teknologi pengajaran dan pembelajaran. Inovasi ini tidak mempengaruhi semua metode pengajaran dan gaya belajar yang sama. Sebaliknya, tergantung kepada sekolah bagaimana mengadopsi Teknologi Informasi dan Komunikasi, kemampuan siswa menggunakan teknologi untuk pembelajaran dan bagaimana guru memilih metode yang tepat ketika dikombinasikan dengan teknologi [13].

SMA Negeri 2 Sungai Penuh merupakan salah satu sekolah di Kota Sungai Penuh yang menjadi favorit bagi siswa-siswi Kota Sungai Penuh dan Kabupaten Kerinci umumnya, yang memiliki laboratorium komputer dan juga dilengkapi dengan fasilitas internet di sekolah. Akan 
tetapi, dalam memanfaatkan internet di SMA Negeri 2 Sungai Penuh masih belum optimal.

Dalam proses pembelajaran Teknologi Informasi dan Komunikasi semester I Kelas XI SMA 2 Sungai Penuh masih menggunakan metode konvensional dimana penyajian dan pendistribusian materi pelajaran dilakukan oleh guru masih dalam pertemuan tatap muka di dalam kelas atau sering disebut pembelajaran konvensional. Dalam hal penyajian materi TIK guru hanya mendiktekan pelajaran didepan kelas dan siswa diminta untuk mencatat ke dalam buku catatan. Hal demikian terkadang menghabiskan waktu yang seharusnya dapat digunakan untuk kegiatan diskusi yang dapat menambah pengetahuan siswa dan membuat siswa kurang memahami akan materi yang dipelajarinya.

Mata Pelajaran Teknologi Informasi dan Komunikasi semester I kelas XI SMA diselenggarakan didalam kelas memiliki keterbatasan - keterbatasan yang dapat menghambat proses penyampaian ilmu pengetahuan yang berkembang demikian cepat. Beberapa keterbatasan bisa disebabkan karena masalah waktu dan tempat. Maka perlunya adanya media di dalam didalam mata pembelajaran TIK yaitu dengan menerapkan media e-learning berbasis video agar tujuan pembelajaran dapat tercapai.

Berdasarkan kondisi tersebut dengan adanya proses pembelajaran secara online dengan memanfaatkan jaringan internet seperti penerapan media e-learning berbasis video. Guru dapat memberi materi pelajaran dengan cara mengupload ke sistem $e$ learning sehingga tidak perlu lagi meminta siswa untuk menulis. Siswapun dapat mengambil materi pelajaran dengan cara mendownload dan mempelajarinya terlebih dahulu sebelum proses pembelajaran dalam kelas dilaksanakan, sehingga print out dari modul pembelajaran yang didownload dari e-learnig dapat dijadikan sebagai catatan bagi siswa.
Pemakaian media e-learning berbasis video dalam proses pembelajaran dapat membangkitkan minat dan motivasi dalam kegiatan belajar, sehingga memepengaruh pola fikir siswa. Penggunaan media $e$ learning pada tahap orientasi pengajaran akan sangat membantu efektifitas dalam tatap muka pembelajaran.

Media E-Learning berbasis video ini merupakan pengembangan dari Media Pembelajaran yang telah ada sebelumnya. Media E-Learning tersebut belum dilengkapi video sedangkan media e-learning yang dirancang ini adalah media e-learning dengan menggunakan video dan forum diskusi serta chat.

Media E-learning berbasis Video yang dapat memberi manfaat yaitu meningkatkan proses pengaksesan internet di sekolah oleh guru dan siswa, dan memperkenalkan manfaat jaringan internet untuk pembelajaran pada para siswa kelas XI SMA Negeri 2 Sungai Penuh yang mana pada saat ini kebanyakan siswa mengenal internet untuk hal-hal lain di luar proses pembelajaran seperti jaringan sosial yaitu Facebook dan Twitter. Dengan adanya Media E-learning berbasis Video, jumlah siswa yang dapat ikut berpartisipasi aktif dalam pembelajaran dapat meningkat dibandingkan belajar secara konvensional di ruang kelas.

Teknologi internet dengan media $e$ learning berbasis video dapat menjadi terobosan yang efektif untuk mengatasi masalah hubungan antara Guru dan Siswa dalam mengolah informasi materi pelajaran. Program sajian materi pelajaran yang menarik, interaktif dan konstruktif dapat mendorong motivasi belajar yang kuat pada siswa, sehingga mereka dapat memahami siswanya kapan dan dimana saja. Agar dapat memanfaatkan teknologi internet dalam pembelajaran, guru dan siswa dituntut untuk memiliki sikap positif terhadap teknologi tersebut, memiliki kreativitas tinggi, memiliki pengetahuan yang memadai tentang teknologi informasi, memiliki 
keterampilan dalam menggunakan komputer dan alat teknologi informasi lainnya.

\section{METODE}

Penelitian ini dilaksanakan dengan menggunakan pendekatan penelitian pengembangan (Development Research) dengan Model IDI (Instructional Development Institute). Pendekatan penelitian pengembangan (Development Research) yaitu pendekatan penelitian yang dikemukakan oleh Akker. Proses penelitian dimulai dari aktivitas yaitu: analisis pendahuluan, perancangan, evaluasi dan revisi [14].

\section{Prosedur Pengembangan}

1. Analisis Kebutuhan

Analisis kebutuhan merupakan langkah awal dalam penelitian pengembangan. Pada tahap ini peneliti menganalisis materi pokok untuk dikembangkan dalam perancangan media $e$ learning berbasis video yang sesuai dengan kompetensi dasarnya, menganalisis karakteristik siswa, yang meliputi latar belakang kemampuan, dan menganalisis kemampuan guru dalam mengatasi keterbatasan media dalam kegiatan pembelajaran TIK di sekolah.

\section{Perancangan}

Media e-learning berbasis video yang dikembangkan akan disesuaikan dengan Mata pelajaran Teknologi Informasi dan Komunikasi untuk kelas XI Sekolah Menengah Atas.

Langkah yang dilakukan yaitu dengan menentukan konsep-konsep utama yang terdapat pada Teknologi Informasi dan Komunikasi untuk Kelas XI. Konsep ini dikembangkan sedemikian rupa sehingga mudah dipahami siswa. Konten Media $e$ learning yang dirancang dengan open source Moodle berupa video, latihan/Quis, forum diskusi, dan Rekaman data yang sesuai dengan konsep Teknologi Informasi dan Komunikasi kelas XI SMA, dengan berpedoman pada buku pedoman TIK Kelas
XI SMA. Dipilih open source Moodle karena kompetibel dan sesuai untuk perancangan serta pengembangan e-learning [15].

3. Evaluasi/Revisi

Pada tahap ini produk yang telah dibuat akan dievaluasi, dengan mengujicobakan ke pengguna (guru dan siswa) pada kelompok kecil. Saran dan komentar dari pengguna digunakan untuk merevisi rancangan media.

[14] mengemukakan bahwa satu dari tiga kriteria kualitas Media e-learning berbasis video adalah kepraktisan. Suatu media dikatakan praktis berarti produk mudah digunakan oleh guru dan siswa. Disamping itu, kualitas sistem dan kualitas informasi menjadi pendorong utama niat untuk menggunakan dan kepuasan terhadap e-learning yang dirancang [16], [17].

\section{Tahap Praktikalitas}

Praktikalitas adalah tingkat keterpakaian Media e-learning berbasis video dalam kegiatan belajar, yaitu melaksanakan percobaan pengajaran dengan menggunakan Media e-learning berbasis video yang telah direvisi berdasarkan penilaian pengguna. Media e-learning berbasis video memiliki praktikalitas yang tinggi apabila bersifat praktis dan mudah pengadministrasiannya. Dalam artian mudah digunakan, mudah pemeriksaannya serta lengkap dengan petunjuk yang jelas. Tahap ini dilakukan uji coba terbatas pada siswa kelas XI SMA Negeri 2 Sungai Penuh. Untuk menentukan praktikalitas media e-learning berbasis video untuk Mata Pelajaran Teknologi Informasi dan Komunikasi Kelas XI, peneliti menggunakan lembar observasi guru dan anket kepraktisan.

\section{Instrumen Penelitian}

Adapun instrumen penelitian yang dikembangkan untuk mengumpulkan data dalam penelitian ini sebagai berikut:

1. Lembar anket kepraktisan Media elearning berbasis video oleh guru dan siswa. [18] mendefinisikan anket sebagai sebuah 
daftar pertanyaan atau pernyataan yang harus diisi oleh responden yang akan dievaluasi. Anket kepraktisan ini akan diisi oleh pengguna yaitu guru dan siswa.

Untuk siswa dari anket kepraktisan yang dilihat adalah minat siswa, proses penggunaannya, peningkatan keaktifan siswa dan waktu siswa dalam mempelajari Mata Pelajaran Teknologi Informasi dan Komunikasi. Sedangkan untuk guru aspek yang dilihat yaitu Aspek Akses E-Learning, Aspek materi, Aspek penyajian, Aspek Media E-Learning Berbasis Video.

\section{Teknik Analisis Data}

Teknik analisis data yang digunakan adalah teknik analisis data deskriptif, yakni dengan mendeskripsikan kepraktisan dengan menggunakan media e-learning berbasis video pada Mata Pelajaran Teknologi Informasi dan Komunikasi Kelas XI SMA. Anket praktikalitas media e-learning berbasis video dideskripsikan dengan teknik analisis frekuensi data dengan rumus:

Skor nilai ideal $\frac{\text { skor rata-rata }}{\text { skor maksimun }} \times 100 \%$

Dengan kategori nilai pencapaian responden digunakan klasifikasi menurut [19] dalam tabel di bawah ini:

Tabel 1. Kategori Kepraktisan Media ELearning Berbasis Video

\begin{tabular}{ccc}
\hline No & $\begin{array}{c}\text { Tingkat } \\
\text { pencapaian (\%) }\end{array}$ & Kategori \\
\hline 1 & $90-100$ & Sangat praktis \\
\hline 2 & $80-89$ & Praktis \\
\hline 3 & $65-79$ & Cukup praktis \\
\hline 4 & $55-64$ & Kurang praktis \\
\hline 5 & $0-54$ & Tidak praktis \\
\hline \multicolumn{3}{c}{$\begin{array}{c}\text { Sumber: [19] } \\
\text { Anket praktikalitas ini diisi oleh }\end{array}$} \\
pengguna yaitu guru dan siswa, untuk \\
melihat sejauh mana kepraktisan dari media \\
yang dirancang.
\end{tabular}

\section{Hasil dan Pembahasan}

Desain Media E-Learning berbasis video untuk mata pelajaran Teknologi Informasi dan Komunikasi dirancang berdasarkan analisis kebutuhan (Needs assessment). Kegiatan ini dimulai dari melakukan pengamatan langsung terhadap kegiatan belajar siswa, analisis materi dan analisis karakteristik siswa.

Hasil dari analisis kebutuhan yang diperoleh melalui pengamatan di Kelas XI Semester 1 SMA Negeri 2 Sungai Penuh adalah masih terbatas dan tidak tersedianya jaringan internet, hal ini mengakibatkan siswa sulit untuk memahami pembelajaran yang dilakukan karena materi pembelajaran harus langsung di uji coba. Disamping itu, guru juga mengalami kesulitan untuk menemukan cara yang tepat dalam penyajian materi aplikasi internet karena materi ini tidak bisa disajikan dengan metode ceramah dan mencatat (pembelajaran masih monoton dan terpusat pada guru). Proses pembelajaran tidak akan berjalan secara optimal dikarenakan keterbatasan waktu dan tempat, materi aplikasi internet merupakan materi semester I kelas XI SMA.

Keterbatasan yang terdapat dalam kegiatan pembelajaran Teknologi Informasi dan Komunikasi ini mengakibatkan suasana belajar menjadi tidak kondusif dan tujuan dari pembelajaran sangat sulit tercapai.

Hasil dari analisis materi adalah materi yang dikembangkan dalam Pembelajaran Teknologi Informasi dan Komunikasi ini tentang Aplikasi Internet. Berdasarkan Prosedur Pelaksanaan Pembelajaran Teori di SMA tentang mata pelajaran Teknologi Informasi dan Komunikasi pada materi Aplikasi Internet, Standar Kompetensi yang harus dicapai oleh siswa adalah "diharapkan agar siswa dapat menggunakan aplikasi internet"

Berdasarkan analisis karekter siswa diketahui bahwa siswa pada umumnya berasal dari karakter yang berbeda baik dari yang memiliki fasilitas internet dan yang 
tidak memiliki internet memberikan perbedaan kecepatan dalam memahami materi Aplikasi Internet. Guru TIK SMA Negeri 2 Sungai Penuh belum melakukan kegiatan analisis terhadap karakteristik siswa ini, dan belum mempunyai inisiatif untuk mengembangkan sebuah media pembelajaran yang layak sesuai dengan konten materi ajar. Siswa hanya diberikan pelajaran dengan kondisi yang terbatas yaitu proses pembelajaran masih menggunakan pendekatan-pendekatan tradisional seperti mencatat, mendengarkan dan mengerjakan latihan sehingga proses pembelajaran masih memberi penekanan pada konsep-konsep yang terdapat dalam buku (Conceptual Learning), dan kurang memanfaatkan lingkungan dan sumber-sumber pembelajaran yang ada di lingkungan sekitar (Contextual Teaching and Learning).

Hal inilah yang menyebabkan siswa kurang termotivasi untuk menemukan sendiri hal-hal baru yang dapat dijadikan sebagai pengalaman dalam proses pembelajaran. Sehingga guru untuk membuat sebuah media pembelajaran, setelah menganalisis karakteristik siswa seorang guru juga membutuhkan keterampilan dan keahlian dalam membuat media pembelajaran yang baik untuk siswa.

Media E-learning Berbasis Video dirancang berdasarkan hasil dari analisis kebutuhan. Berikut ini tampilan dari media E-learning Berbasis Video.

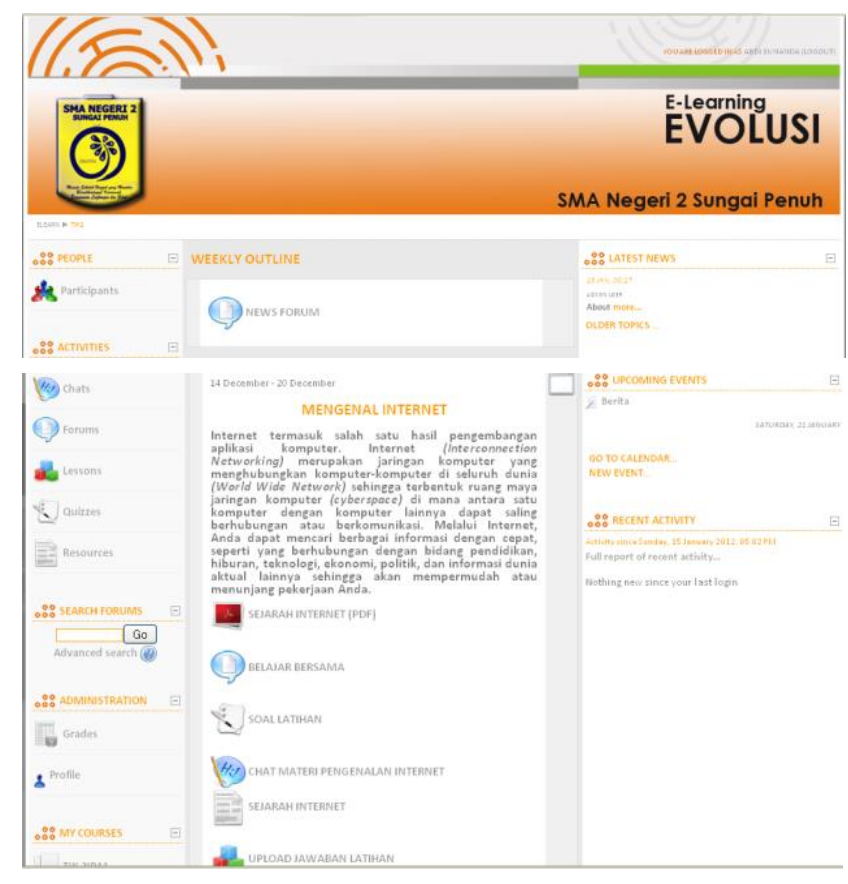

\section{Gambar 1. Desain Media E-Learning Berbasis Video}

Berdasarkan uji coba, aspek materi dan urutan penyajian materi "aplikasi internet" dalam Media E-Learning berbasis video sudah baik dalam penggunaannya. Kelengkapan materi "aplikasi internet" dalam Media E-Learning berbasis video juga sudah baik sehingga dengan kelengkapan yang ada pada Media E-Learning berbasis video sudah dapat diujicobakan terhadap siswa. Konsep yang disajikan melalui Media E-Learning berbasis video ini sudah sesuai dengan konsep pembelajaran Teknologi Informasi dan Komunikasi dimana materi dibagi atas tiga garis besar yaitu Mengenal Internet, Menggunakan Internet untuk Mencari Informasi dan Menggunakan Email.

Pada aspek cara penyajian materi aplikasi internet disajikan melalui video dan teks yang sudah sistematik dan logis. Penyajian materi aplikasi internet sudah baik sehingga penyampaian materi melalui video dapat diujicobakan langsung dengan menggunakan Media E-Learning berbasis video. Ilustrasi dalam pembelajaran sudah 
memperjelas konsep materi aplikasi internet, dengan demikian penggunaan ilustrasi dapat membantu siswa dalam memahami pembelajaran Teknologi Informasi dan Komunikasi.

Pada aspek desain Media E-Learning Berbasis Video, desain interface yang dibuat dalam Media E-Learning Berbasis Video sudah cukup baik namun perlu dilakukan perbaikan dalam desain interface Media $E$ Learning Berbasis Video. Penggunaan teks dan grafik dalam Media E-Learning Berbasis Video cukup baik. Tetapi, penggunaan video dan interaktifitas dalam Media E-Learning Berbasis Video masih sudah baik, sehingga masih dibutuhkan sedikit revisi agar media ini menjadi lebih interaktif dan video yang ditampilkan mampu memberikan penjelasan secara detail tentang materi. Untuk kecepatan sistem dan kemudahan panel dalam penggunaan Media E-Learning Berbasis Video sudah baik.

Berdasarkan hasil uji coba, dapat disimpulkan bahwa desain pertama yang dilakukan pada aspek perancangan Media $E$ Learning berbasis video sudah baik, tetapi masih perlu dilakukan beberapa perbaikan tentang penyempurnaan video yaitu penambahan keterangan pada setiap pokok bahasan dan pembuatan video dengan menggunakan windows terbaru..

Selanjutnya adalah pada aspek video Media E-Learning. Aspek-aspek yang diuji cobakan adalah video dalam Media $E$ Learning yang berhubungan dengan materi, umpan balik siswa, minat siswa, motivasi siswa, memperjelas isi penyajian, dan tampilan gambar serta efek dalam pembelajaran, efek suara, dan sikronisasi dinamika video dan audio.

Berdasarkan hasil uji uji coba dilakukan kepada guru dan beberapa siswa, dapat disimpulkan bahwa rancangan pertama video dalam Media E-Learning sudah baik, walaupun masih ada beberapa bagian yang harus disempurnakan. Rancangan video yang sudah selesai seperti pada gambar 2 .

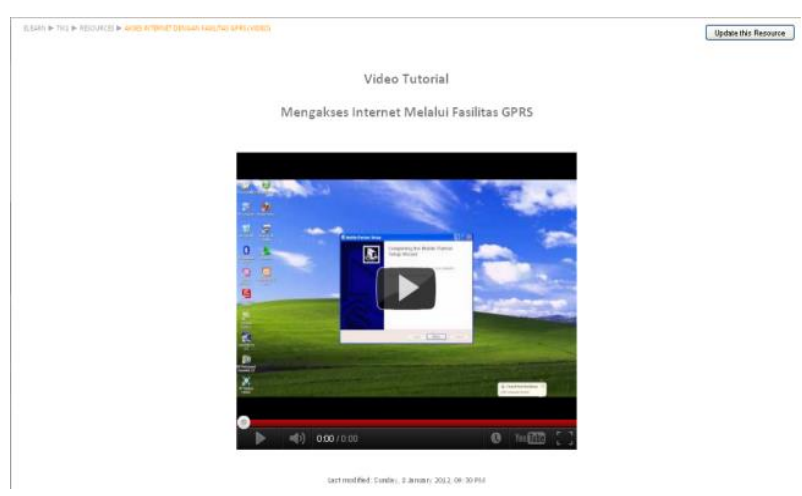

Gambar 2. Rancangan video pada Media ELearning

Pada tahap kepraktisan Media ELearning berbasis video juga akan dimintai masukan oleh guru melalui anket kepraktisan, hasilnya menunjukkan bahwa Media E-Learning berbasis video untuk materi Aplikasi internet yang dikembangkan ini adalah menarik oleh guru dan mudah digunakan. Proses pembelajaran dengan menggunakan Media E-Learning berbasis video ini membantu guru dalam menyampaikan materi pembelajaran. Disamping itu penggunaan Media ELearning berbasis video ini sangat menunjang siswa dalam mempelajari materi aplikasi internet. Pembelajaran dengan menggunakan Media E-Learning berbasis video ini dapat membuat siswa meningkatkan aktifitas, membantu kemandirian belajar dan dapat membantu menumbuhkan pengalaman belajar siswa dalam setiap kegiatan pembelajaran. Menurut guru, Media E-Learning berbasis video yang dikembangkan ini sudah sesuai untuk materi aplikasi internet yang diajarkannya. Berdasarkan hasil analisis Kepraktisan oleh Guru pada Desain Pertama diperoleh $84 \%$ dengan kategori praktis. Saran dari guru terhadap Desain Pertama yaitu kembangkan interaktifitas terhadap siswa.

Sedangkan anket kepraktisan Media ELearning berbasis video yang diisi oleh siswa, juga disimpulkan bahwa desain pertama yang dirancang sudah praktis. 
Tabel 2. Komentar Siswa terhadap Desain Pertama

\begin{tabular}{lcc}
\hline Nama siswa & Skor & Kesimpulan \\
\hline Abdi Sunanda & 84 & Praktis \\
\hline Ahmad Johor & 81 & Praktis \\
\hline Ari Purnomo & 86 & $\begin{array}{l}\text { Sangat } \\
\text { praktis }\end{array}$ \\
\hline
\end{tabular}

Hasil evaluasi tiga orang siswa di atas menunjukkan desain pertama sudah praktis. Walaupun demikian, masih ada beberapa hal yang harus diperbaiki agar Media ELearning berbasis video yang digunakan dalam kegiatan pembelajaran dapat membantu siswa dalam memahami materi aplikasi internet. Hal yang harus diperbaiki dalam Media E-Learning berbasis video adalah sistemnya. Sehingga Media $E$ Learning berbasis video selain untuk pembelajaran juga untuk melatih siswa agar dapat belajar mandiri.

Sejalan ujicoba dan praktikalitas media maka perbaikan dilakukan dan diuji coba kedua kalinya khususnya pada bagian materi harus lebih simple, ringkas dan sederhana sehingga pengguna tidak berlama-lama membaca tulisan yang akan berakibat kebosanan dan kejenuhan, sedangkan aspek lainnya tidak begitu prinsip dalam perbaikan.

Sedangkan pada tahap kepraktisan Media E-Learning berbasis video, guru menyatakan daya tarik Media E-Learning berbasis video untuk materi aplikasi internet yang dikembangkan ini sangat tinggi karena Media E-Learning berbasis video ini sangat mudah untuk digunakan. Pembelajaran dengan menggunakan Media E-Learning berbasis video ini sangat menunjang siswa dalam mempelajari materi aplikasi internet. Penggunaan video dalam e-learning akan memberikan dampak terhadap efektifitas belajar [20]. Media E-Learning berbasis video ini juga sangat mudah digunakan oleh guru dalam menjelaskan pembelajaran Teknologi Informasi dan Komunikasi untuk materi aplikasi internet. Proses pembelajaran dengan menggunakan Media E-Learning berbasis video ini sangat membantu guru dalam menyampaikan materi pembelajaran. Disamping itu, juga dapat membuat siswa lebih aktif, sehingga pembelajaran menjadi lebih menarik dan tidak monoton, Semua kegiatan yang dilakukan dalam Media $E$ Learning berbasis video dapat membantu siswa untuk memahami setiap materi yang disampaikan. Perancangan yang sesuai kaidah e-learning yang baik dapat membantu proses pembelajaran dan lingkungan belajar dengan e-learning membantu mempengaruhi prestasi siswa [21].

Media E-Learning berbasis video yang dikembangkan ini menurut guru sudah sesuai untuk materi aplikasi internet yang diajarkannya. Dengan adanya kesesuaian materi, guru sangat mudah untuk menyampaikan materi tentang aplikasi internet kepada siswa. Berdasarkan hasil analisis Kepraktisan oleh Guru pada Desain kedua diperoleh $96 \%$ dengan kategori sangat praktis.

Berdasarkan pengisisan anket kepraktisan Media E-Learning berbasis video oleh guru maka dapat disimpulkan bahwa desain Media E-Learning berbasis video kedua yang dilakukan menunjukkan bahwa Media E-Learning berbasis video sudah sangat praktis. Sedangkan komentar guru terhadap desain kedua ini adalah $E$ Learning ini sangat membantu dalam proses pembelajaran

Setelah desain kedua diuji cobakan pada enam orang siswa sebagai kelompok kecil (Small group). Hal ini dilakukan untuk melihat praktikalitas media pembelajaran, sebelum diujicobakan dalam skala besar. Diperoleh hasil seperti pada tabel 3.

Tabel 3. Komentar Siswa Kelompok Kecil (Small Group) terhadap Desain Kedua

\begin{tabular}{lcc} 
Nama siswa & Skor & Kesimpulan \\
\hline Abdi Sunanda & 94 & Sangat praktis \\
\hline Ahmad Johor & 95 & Sangat Praktis \\
\hline Ari Purnomo & 92 & Sangat Praktis \\
\hline
\end{tabular}




\begin{tabular}{lcl}
\hline Gopal Adya A & 94 & Sangat Praktis \\
\hline Isma Fitria & 100 & Sangat Praktis \\
\hline M. Irfan & 93 & Sangat Praktis \\
\hline
\end{tabular}

Dari hasil pengisian anket oleh siswa terlihat minat siswa, proses penggunaannya, peningkatan keaktifan siswa dan waktu siswa dalam mempelajari Mata Pelajaran Teknologi Informasi dan Komunikasi. Kondisi ini sejalan dengan pendapat bahwa dengan e-learning yang diterapkan dalam pembelajaran berdampak kepada peningkatan motivasi dan kompetensi siswa [22].

Dari hasil praktikalitas yang diujicobakan kepada siswa terlihat bahwa perancangan media ini sudah layak digunakan, namun penelitian dibatasi sampai pada uji coba praktikalitas pada skala kecil karena keterbatasan kemampuan dan anggaran. Disamping itu, tantangannya jika ada beberapa siswa yang menemui kendala dalam proses e-learning ini berakibat menurunnya interaksi siswa [23]. Sehingga dalam e-learning interaksi yang berkelanjutan menjadi kunci kesuksesan pembelajaran dengan e-learning [24]

\section{SimpUlan}

Penelitian pengembangan ini menghasilkan produk yaitu Media $E$ Learning berbasis video untuk materi aplikasi internet pada mata pelajaran Teknologi Informasi dan Komunikasi untuk siswa kelas XIIPA1 Semester 1 SMA Negeri 2 Sungai Penuh. Hasil penelitian menunjukan bahwa Media E-Learning berbasis video yang dikembangkan praktis digunakan sebagai media pembelajaran. Praktikalitas Media E-Learning berbasis video telah dinilai oleh guru, diantaranya bidang perancangan Media E-Learning berbasis video dan bidang Video Media $E$ Learning. Sedangkan kepraktisan dinilai oleh guru TIK SMA dan siswa kelas IX SMA. Sehingga Media E-Learning berbasis video ini sudah memenuhi kriteria praktis. Bahwa dari pelaksanaan uji coba baik kepada guru maupun siswa memperlihatkan sikap positif mulai dari awal sampai akhir pelaksanaan menggunakan Media $E$ Learning berbasis video [25], [26], [27], [28], [29]. Rancangan Media E-Learning berbasis video telah praktis dan dapat digunakan dalam pembelajaran di SMA dan dapat dikembangkan serta digunakan pada mata pelajaran yang berbeda

\section{Ucapan Terima Kasih}

Ucapan terima kasih kepada SMA Negeri 2 Sungai Penuh khususnya Kepala Sekolah Bapak Suhatman Jaya, M.Pd yang telah memberikan kesempatan untuk melakukan penelitian, Bapak Drs. Dharma Liza Said, M.T dan bapak Muhamaad Adri, S.Pd, M.T sebagai tim yang memberikan masukan perbaikan produk media e-learning. serta Hendra Hidayat, M.Pd, Adlia Alfi Riani, M.Pd, Desy Fardilla, M.Pd dan Melisa, M.Pd.

\section{Referensi}

[1] Sanjaya, Wina. 2007. Strategi Pembelajaran berorientasi standar proses pendidikan. Jakarta: Kencana Prenada Media

[2] Munir. 2009. Pembelajaran Jarak jauh Berbasis teknologi Informasi dan Komunikasi. Bandung: Alfabeta.

[3] Muhammad Adri,. 2008. Pengembangan Belajar Model Belajar Jarak Jauh FT UNP dengan P4TK Medan dalam rangka perluasan kesempatan belaja dan Multimedia-pengajaran. From http://ilmukomputer.org. Download 28 Agustus 2011

[4] Bajraktarevic, N., \& Fullick, P. (2003). ILASH: Incorporating learning strategies in hypermedia. In Paper presented at the workshop on adaptive hypermedia and adaptive web-based systems (AH2003), Twelfth international world wide web conference, Budapest, Hungary.

[5] Chua, H., Liaob,M., Chenc, T., Lind, C., \& Chen, Y. (2011). Learning case adaptation for problem-oriented e- 
learning on mathematics teaching for students with mild disabilities. Expert Systems with Applications, 38(3), 12691281.

[6] Manochehr, N. N. (2006). The influence of learning styles on learners in elearning environments: An empirical study. Computers in Higher Education Economic Review, 18, 10-14.

[7] Mustafa, Y. E. A., \& Sharif, S. M. (2011). An approach to adaptive elearning hypermedia system based on learning styles (AEHS-LS): Implementation and evaluation. International Journal of Library and Information Science, 3(1), 15-28.

[8] Papanikolaou, K., Grigoriadou, M., Kornilakis, H., \& Magoulas, G. (2003).Personalizing the interaction in a web-based educational hypermedia system:The case of INSPIRE. User Modelling and User-adapted Interaction, 13(3), 213-267.

[9] Popescu, E. (2010). Adaptation provisioning with respect to learning styles in a web-based educational system: An experimental study. Journal of Computer Assisted Learning, 26(4), 243-257.

[10] Sangineto, E., Capuano, N., Gaeta, M., \& Micarelli, A. (2008). Adaptive course generation through learning styles representation. Universal Access in the Information Society, 7(1), 1-23.

[11] Wang, F. H. (2008). Content recommendation based on educationcontextualized browsing events for webbased personalized learning. Educational Technology \& Society, 11(4), 94-112.

[12] Wang, C., Wanga, D., \& Lin, J. (2010). ADAM: An adaptive multimedia content description mechanism and its application in web-based learning. Expert Systems with Applications, 37(12), 3639-8649.

[13] Castillo-Merino, David \& SerradellLópez, Enric, "An analysis of the determinants of students' performance in e-learning," Computers in Human Behavior, 30 (2014) 476-484.

[14] Akker. 1999. Design Approaches and Tools in Education and Training. Dordrecht: Kluwer Academic Publishers

[15] Islam, A.K.M. Najmul, "E-learning system use and its outcomes: Moderating role of perceived compatibility" Telematics and Informatics, 33 (2016) 48-55.

[16] Mohammadi, Hossein, "Factors affecting the e-learning outcomes: An integration of TAM and IS success model," Telematics and Informatics, 32 (2015) 701-719.

[17] Maldonado, U.P.T; Khan, G.F; Moon, J; \& Rho, J.J," E-learning motivation and educational portal acceptance in developing countries" Online Information Review, Vol. 35 No. 1, 2011, pp. 66-85

[18] Sugiyono. 2007. Metode Penelitian Pendidikan, Pendekatan Kuantitatif, Kualitatif dan R\&D. Bandung: Penerbit Alfabeta

[19] Sudjana, Nana \& Rivai, Ahmad. 2001. Teknologi Pembelajaran. Bandung: Sinar Baru Algensindo.

[20] Sahasrabudhe, Vikas \& Kanungo, Shivraj, "Appropriate media choice for e-learning effectiveness: Roleof learning domain and learning style" Computers \& Education, 76 (2014) 237-249

[21] Hoskins, S. L., \& van Hooff, J. C. (2005). Motivation and ability: Which students useonline learning and what influence does it have on their achievement? British Journal of Education Technology, 2(36), 177-192.

[22] Novo-Corti, Isabel; VarelaCandamio, Laura; \& Ramil-Díaz, María. "E-learning and face to face mixed methodology: Evaluating effectivenessof e-learning and perceived satisfaction for a microeconomic course using 
theMoodle platform." Computers in Human Behavior. 29 (2013) 410-415.

[23] Davies, J., \& Graff, M. (2005). Performance in e-learning: online participation and student grades. British Journal of Educational Technology, 36(4), 657-663.

[24] Su, B., Bonk, C. J., Magjuka, R. J., Liu, X., \& Lee, S. (2005). The importance of interaction in web-based education: a program-level case study of online MBA courses. Journal of Interactive Online Learning, 4(1), 1-19.

[25] Akpinar, Y., Bayramoglu, Y. (2008). Promoting teachers' positive attitude towards web use: a study in web site development, The Turkish Online Journal of Educational Technology TOJET, 7(3), Article 5, Available on http://www.tojet.net/articles/735.doc

[26] Gray, D. S., Souter, N. (2002), Secondary Science Teachers Use Of, and Attitudes Towards, ICT In Scotland, Glasgow, University of Strathclyde,
Available on http://www.iubs.org/cbe/papers/souter_S econdary.html

[27] Gulbahar, Y. (2008). Improving the technology integration skills of prospective teachers through practice: A case study, The Turkish Online Journal of Educational Technology - TOJET, 7(4), Article 8, Available on http://www.tojet.net/articles/748.doc

[28] Stevanovic, V., Stevanovic, M., Pejcic, B. (2009). Spremnost nastavnika na razlicitim nivoima obrazovanja za eucenje (Readiness of the teachers on different school levels for e-learning), XIV congress JISA DICG, Herceg Novi, http://www.jisa.rs

Tearle, P., Golder, G. (2008). The use of ICT in the teaching and learning physical education in compulsory education: how do we prepare the workforce of the future? European Journal of Teacher Education, 31(1), 55-72. 